\title{
MANOBO ORAL NARRATIVES AND THEIR EDUCATIONAL IMPLICATIONS
}

\author{
Lenny Joy E. Sardido ${ }^{1}$, Reita C. Palma ${ }^{2}$ \\ ${ }^{1}$ Master of Arts in Filipino, Professional Schools, University of Mindanao, Davao City, Philippines \\ ${ }^{2}$ EdD, Professor, University of Mindanao, Davao City, Philippines
}

Article DOI: https://doi.org/10.36713/epra9381

DOI No: $10.36713 /$ epra9381

\begin{abstract}
This study aimed to study, collect, analyze, and record the oral narratives of the Manobo tribe in Barangay Magulibas, Jose Abad Santos, Davao Occidental. Also, this study aims to determine each value and educational implication found in the oral narratives collected. This study uses qualitative-narrative analysis composed of ten research participants, nine Manobo tribal elders, and one tribal literacy teacher. The researcher collected thirty oral narratives of Manobo, consisting of eight legends and twenty-two folktales, which were identified using Eugenio's Classification of Oral Narratives. The researcher uses the Triangular Translator to explain the guide questionnaire, which is translated from the Manobo language to Visayan language. The values found from the collected oral narratives were based on Classification of Values by Andres. Findings reveal that the values and educational implications found in the oral narratives of Manobo mirror the culture, tradition, and way of living of the tribe. These collected oral narratives of the Manobo will be used to learn and guide future researchers.

KEYWORDS: oral narratives, Manobo, private school, values, Philippines
\end{abstract}

\section{INTRODUCTION}

Since before and in the present decade, the oral narratives are significant in the socio-cultural community, including the learnings, arts, ideas, and culture of each tribe (Cajetas-Saranza, 2016). The Philippines is known for its diverse culture and is composed of different tribes. The Manobo is one of the country's tribes known for its unique style of language, beliefs, and oral narratives. Oral narratives display the culture of each tribe which gives value, knowledge, and information on their lifestyle that allows us to trace the customs and traditions that exist in our culture (Sumaljag, 2016).

However, these oral narratives are unpreserved as time goes by, given that the present generation missed the chance to give importance and value to it (Banuag-Lopez and Payapaya, 2019). Manobo oral narratives are needed to be documented, written down and, shared because it has a significant value that can be handed down from one generation to the other, and it helps preserve the Manobo literature and its cultural heritage by exploring the literature. Thus, it is essential to preserve Manobo oral narratives before it is completely lost.

\section{OBJECTIVES}

This study aims to collect, analyze, and document the Manobo oral narratives of Barangay Magulibas, Jose Abad Santos, Davao Occidental to identify the collected narratives' values and determine their educational implications.

\section{METHODS}

This research uses qualitative narrative analysis, which is the collected stories will be the data. The study was conducted in Barangay Magulibas, Jose Abad Santos, Davao Occidental. The participants of this study were nine Manobo tribal elders and one tribal literacy teacher. The following standards were established: (1) the participants are will-verse in Manobo dialect, culture, history, and a resident of Municipality of Jose Abad Santos and (2) have the ability in narrating the oral narratives of the Manobo Tribe.

During the study, a Key Informant Interview (KII) with 10 participants was used in gathering the data needed for the study. There were two types of data gathered, the first one is about the history and lifestyle of the Manobos, and the second one is their oral narratives. Audio-recorder was used during the 
data gathering to ensure the correctness of data. The oral narratives gathered were in the Manobo language, and the translator transcribed the gathered data into Cebuano. The researcher translated the Cebuano data into the Filipino language as part of the researchers' objectives. Meaning-Based Translation of Larson was used in this study where the thought of the translated language is accurately translated and still preserving its original thought (Sayadani et.a, 2019)

The collected Manobo oral narratives were analyzed according to the following categories: Classification of Narratives of Eugenio (1993) and Classification of Values in the oral narratives of Andres (1985). The educational implications of this study were derived from the values gathered from the collected narratives.

\section{RESULTS AND DISCUSSION}

The Manobo tribe generally found in the province of Sarangani, Agusan, Bukidnon, Surigao del Sur, Davao Region, Cotabato and located in some Municipalities of Davao Occidental such as Jose Abad Santos, Sarangani, Don Marcelino, Sta. Maria and Malita.

The Manobo of Barangay Magulibas has its own way of their belief, culture, tradition, and teachings that defines their own identity as a tribe. They believed in the supernatural beings called "Timanem/Diwata" or God, who helps and guides them to overcome challenges in their day-to-day living (Ancestral Domain Sustainable and Protection Plan 2020).

Table 1

The classification of folk narratives according to Eugenio (1993)

\section{ALAMAT (LEGENDS)}

A. ALAMAT NG KABAYANIHAN (Heroic Legends)

1. Datu Magasa

B. ALAMAT NA PATUNGKOL SA MGA SUPERNATURAL NA NILALANG (Legend's recounting encounters with supernatural beings)

2. Ang Misteryosong Bukid ng Carahayan

C. ALAMAT NG PANGALAN NG ISANG LUGAR (Place Name Legends)

3. Alamat ng Magulibas

4. Alamat ng Sitio Abana

5. Alamat ng Sitio Puso

6. Alamat ng Calian

7. Ang Alamat ng Bibig ng Baboy

8. Alamat ng Sitio Busaw

\section{KWENTONG-BAYAN (FOLKTALES)}

KWENTONG-BAYAN (FOLKTALES)

A. KWENTO NG MGA HAYOP (Animal Tales)

1. Ang Paniki at ang Umang

2. Ang Kalabaw at Ang Baka

B. KWENTO NG MAHIKA (Marchen o Tales of Magic)

3. Ang Batang Iniwan ng Mama at Papa

C. KWENTONG NOBELISTIK (Novelistic Tales)

4. Ang Dalaga at Ang Langit

5. Ang Dalawang Unggoy

6. Ang Dalawang Mag-asawa

7. Ang Matandang Babae at Lalaki na Nangloko ng mga Binata

8. Ang Mga Bata

9. Ang Mahiwagang Singsing

10. Ang Batang Mabait at ang Higante

D. KWENTONG RELIHIYOSO

/DIDAKTIKO

(Religious/Didactic Tales)

11. Ang Unggoy at Matanda

12. Si Juan na Mangingisda

13. Ang Taong Malikot ang Kamay

E. KWENTO NG KALOKOHAN (Human Trickster Tales)

14. Kaldero ni Habuchi

15. Ang Natamo ng Pamilya

16. Si Pedro at Higante

17. Ang Kwento ni Sumi

18. Ang Simula ng Paggamit ng Damit

F. KWENTONG MAY KABALBALAN (Numskull Tales)

19. Binatabog

20. Si Bingi at Si Bulag

21. Huwag Kayong Iiyak Kapag Walang Ulam

22. Ang Sumaya Clan 


\section{Values found in the Oral Narratives}

Religious Values. Manobo tribes believe in supernatural beings called "Timanem/Diwata" or God. The Manobo view Timanem/Diwata as their savior, and they believe that if they have faith in their Tim 'anem/Diwata they will become successful and survive in their daily living.

Cultural Values. The Manobo oral narratives reveal that cultural values of the Manobo tribe were portrayed thru giving appreciation to the beauty of nature and the abundance of natural resources found in their respective place.

Human Values. In the oral narrative of the Manobo, they human value thru the value of love, humbleness, helpfulness, generosity, kindness, unity, and all the good traits. It is revealed in one of the oral narratives collected in this study.

Political Values. The oral narrative of the Manobo has a political value which is portrayed thru

Table 2

The classification of folk narratives, according to Eugenio (1993)

\begin{tabular}{|c|c|c|c|c|c|c|}
\hline ALAMAT (Legends) & REL & CUL & HUM & POL & ECO & SOC \\
\hline 1. Datu Magasa & & & $*$ & $*$ & & \\
\hline 2. Ang Misteryosong Bukid sa Carahayan & & & & & $*$ & \\
\hline 3. Alamat ng Magulibas & & $*$ & & & $*$ & $*$ \\
\hline 4. Alamat ng Sitio Abana & & $*$ & & & & \\
\hline 5. Alamat ng Sitio Puso & & & $*$ & $*$ & & $*$ \\
\hline 6. Alamat ng Calian & & & $*$ & & $*$ & \\
\hline 7. Ang Alamat ng Bibig ng Baboy & & $*$ & & & & \\
\hline 8. Alamat ng Sitio Busaw & & $*$ & & & & $*$ \\
\hline MGA KWENTONG-BAYAN (Folktales) & REL & CUL & HUM & POL & ECO & SOC \\
\hline 9. Ang Paniki at Ang Umang & & $*$ & $*$ & & & \\
\hline 10. Ang Kalabaw at Ang Baka & & & & & & $*$ \\
\hline $\begin{array}{l}\text { 11. Ang Batang Iniwan ng Kanilang Mama at } \\
\text { Papa }\end{array}$ & & $*$ & $*$ & & & \\
\hline 12. Ang Dalaga at Ang Langit & & & & & $*$ & \\
\hline 13. Ang Dalawang Unggoy & & & $*$ & & $*$ & $*$ \\
\hline 14. Ang Dalawang Mag-asawa & & & $*$ & & $*$ & $*$ \\
\hline $\begin{array}{l}\text { 15. Ang Matandang Babae at Lalaki na Nangloko } \\
\text { ng mga Binata }\end{array}$ & & & $*$ & & $*$ & $*$ \\
\hline 16. Ang Mga Bata & & & $*$ & & & \\
\hline 17. Ang Mahiwagang Singsing & & & $*$ & & & $*$ \\
\hline 18. Ang Batang Mabait at Ang Higante & $*$ & $*$ & $*$ & & & \\
\hline 19. Ang Unggoy at Matanda & & $*$ & $*$ & & $*$ & $*$ \\
\hline 20. Si Juan na Mangingisda & & $*$ & $*$ & & $*$ & \\
\hline 21. Ang Taong Malikot ang Kamay & & & $*$ & & & \\
\hline 22. Kaldero ni Habuchi & & $*$ & $*$ & $*$ & & $*$ \\
\hline 23. Ang Natamo ng Pamilya & & & & & $*$ & $*$ \\
\hline 24. Si Pedro at Higante & & $*$ & & $*$ & $*$ & $*$ \\
\hline 25. Ang Kwento ni Sumi & & & $*$ & & & \\
\hline 26. Ang Simula ng Paggamit ng Damit & & $*$ & & & & $*$ \\
\hline 27. Binatabog & & & & $*$ & & \\
\hline 28. Ang Bingi at Ang Bulag & & & & & & $*$ \\
\hline 29. Huwag Kayong Iiyak Kapag Walang Ulam & & & $*$ & & $*$ & $*$ \\
\hline 30. Ang Sumaya Clan & & & & & & $*$ \\
\hline
\end{tabular}

giving authority and being obedient to the command of the needy. The value showed that the leader provides what is asked by people and helps them for each mission to succeed.

Economic Value. The economic value found in the Manobo oral narratives pertains to the daily living and livelihood of the Manobo tribe. It shows that fishing and farming are the common sources of their livelihood, which provides their basic needs to survive.

Social Value. This value was commonly found in Manobo oral narratives, which refers to the relationship of each person in social gatherings, just like celebrations, feasts, or doing rituals. It is revealed that the Manobo's really value the importance of a family in which there will be no called society if there were no people. 


\section{Educational Implications}

There were educational implications found in this study's oral narratives, which proves that this study can help different organizations. Results show that the Manobo tribe gives authority and importance to their tribal leader, tribal members, and even their own beliefs, culture, and traditions. The collected Manobo oral narratives also help them value their own identity as a tribe. These collected oral narratives can also be used as educational material to teach literature, language, or reading to the students.

The oral narratives can also be shared among the other member of the tribes for them to keep the awareness, values, and preservation of their oral narratives that enable them to appreciate their identity. These narratives help the tribe boost their self-confidence as they interact with different types of society in which they must be proud to contribute to the Philippine Literature. Lastly, the values found in the collected Manobo narratives can be used as a tool for Values Education teachers as the source of information in teaching values information in different institutions.

\section{REFERENCES}

1. Ancestral Domain Sustainable and Protection Plan (2020). Manobo and Blaan Tribes of Jose Abad Santos, Davao Occidental: 22-60

2. Andres, T. D. (1985). Management by Filipino values: A sequel to understanding Filipino values. New Day.

3. Banuag, L. L., \& Payapaya, R. C. (2019). Language use of Manobo students in social networking sites. Asia Pacific Higher Education Research Journal (APHERJ), 6(2).

4. Butina, M. (2015). A narrative approach to qualitative inquiry. Clinical Laboratory Science, 28(3), 190-196.

5. Cajetas-Saranza, R. (2016). Higaonon oral literature: A cultural heritage. US-China Education Review, 6(5), 302-310.

6. De Villa-Gosadan Beatriz, Bro. Arul Rayan (2018). Influence of Education on the Socio-Cultural and Economic Development among the Manobo of Cotabato, Philippines International Journal of Humanities Social Sciences and Education, 5(8): 193-202

7. Eugenio, D. L. (1993). Folklore in Philippine Schools. Philippine studies, 175-190.

8. Graneheim, U. H., Lindgren, B. M., \& Lundman, B. (2017). Methodological challenges in qualitative content analysis: A discussion paper. Nurse education today, 56, 30-31

\section{SUGGESTIONS}

This study suggests that: schools may encourage more students to appreciate and study the different cultures, traditions, and beliefs of each tribe found in the country; schools may include preservation and learning oral narratives of the tribe in the curriculum to give importance to it. Lastly, it helps encourage teachers and students to record, document, and study more about the oral narratives of Manobo for them to appreciate and understand the own way of tribe's culture, beliefs, and tradition.

\section{CONCLUSION}

This study shows that the Philippines is rich in different kinds of literature, which some are commonly found in different tribes across the country's three islands. These oral narratives are one of the Philippines prides who have made great contributions to the literature in the country and around the globe. Furthermore, studying, documenting, and analyzing oral narratives of the Manobo tribe is very important, which helps the tribe preserve their culture, identity, and uniqueness.

9. Guintaos, Cebella (2016). "Manobo Folktales." Dagmay.Online,Tambara,dagmay.online/2016/04/17/ manobo-folktales.

10. Hoshmand, L. T. (2015). Narratology, cultural psychology, and counseling research. Journal of Counseling Psychology, 52(2), 178.

11. Lapez, T. M. C., Jumawid, M. B., Lajera, J. C., Maranga, A. C., \& Molina, S. O. (2017). Tourist Police Officers' Compliance with Republic Act 9593. ACADEME University of Bohol, Graduate School and Professional Studies, 10(1).

12. Masendo, Abraham (2015). "The Manobo Tribe Then and Now: An Ethnography." International Journal of Scientific \& Engineering Research 6.4: 227

13. Sayadani, A., Heydarpour, $Y$., \& Asgharpour, $S$. (2019). The Quality of Meaning-base Translation According to Larson's Theory in Yasrebis Translation of Quran: Case Study of Kahf Surah. Translation Researches in the Arabic Language And Literature, 9(20), 92-59.

14. Sone, E. M. (2018). African oral literature and the humanities: Challenges and Prospects. Humanities, 7(2), 30.

15. Sumaljag, M. V. O. (2009). Blaan Oral Narratives and Their Educational Implications. JPAIR Multidisciplinary Research Journal, 2(1), 1-1. 